\title{
Interactions between Plants and Plant-Soil in Functionally Complex Mixtures including Grass Pea, Faba Bean and Niger, Intercropped with Oilseed Rape
}

\author{
Xavier Bousselin ${ }^{1,2}{ }^{\circledR}$, Nathalie Cassagne ${ }^{2} \oplus$, Alice Baux ${ }^{1}$, Muriel Valantin-Morison ${ }^{3}$, Juan Manuel Herrera ${ }^{1}$, \\ Mathieu Lorin ${ }^{2}$, Marie Hédan ${ }^{2}$ and Joëlle Fustec ${ }^{2, *}$ \\ 1 Agroscope, Plants and Plants Products, Route de Duillier 50, CH-1260 Nyon, Switzerland; \\ xavier.bousselin@agroscope.admin.ch (X.B.); alice.baux@agroscope.admin.ch (A.B.); \\ juan.herrera@agroscope.admin.ch (J.M.H.) \\ 2 USC 1432 LEVA, Ecole Supérieure d'Agricultures, INRAE, SFR 4207 QUASAV, 55 rue Rabelais, \\ F-49100 Angers, France; n.cassagne@groupe-esa.com (N.C.); m.lorin@groupe-esa.com (M.L.); \\ marie.hedan@gmail.com (M.H.) \\ 3 UMR Agronomie, INRAE, AgroParisTech, Université Paris-Saclay, F-78850 Thiverval-Grignon, France; \\ muriel.morison@inrae.fr \\ * Correspondence: j.fustec@groupe-esa.com
}

Citation: Bousselin, $\mathrm{X}$; Cassagne, $\mathrm{N}$.; Baux, A.; Valantin-Morison, M.; Herrera, J.M.; Lorin, M.; Hédan, M.; Fustec, J. Interactions between Plants and Plant-Soil in Functionally Complex Mixtures including Grass Pea, Faba Bean and Niger, Intercropped with Oilseed Rape. Agronomy 2021, 11, 1493. https:// doi.org/10.3390/agronomy11081493

Academic Editor:

Nikolaos Monokrousos

Received: 23 April 2021

Accepted: 21 July 2021

Published: 27 July 2021

Publisher's Note: MDPI stays neutra with regard to jurisdictional claims in published maps and institutional affiliations.

Copyright: (C) 2021 by the authors Licensee MDPI, Basel, Switzerland. This article is an open access article distributed under the terms and conditions of the Creative Commons Attribution (CC BY) license (https:// creativecommons.org/licenses/by/ $4.0 /)$
Abstract: Winter oilseed rape (OSR) can be grown intercropped with frost-sensitive service plant mixtures. This practice may reduce weed pressure and contribute to providing $\mathrm{N}$ for OSR after service plant freezing. However, there is little knowledge of how plants interact together and with the soil in diverse annual crop mixtures. To assess these interactions, two contrasting legume service plants were selected: faba bean and grass pea, as well as a non-legume, the niger plant. OSR and the legumes were then grown in mesocosms alone or intercropped in mixtures of two to four species. The biomass, $\mathrm{N}$ contents, $\mathrm{N}_{2}$ fixation, and soil substrate-induced respiration were measured. A single species mostly drove the total dry biomass and the amount of $\mathrm{N}$ accumulated by the cover, OSR and faba bean for dry weight and $\mathrm{N}$ contents, respectively. Grass pea was highly sensitive to competition with OSR, and its $\mathrm{N}_{2}$ fixation was lower than that of faba bean. The addition of niger did not lead to additional $\mathrm{N}_{2}$ fixation of legumes or total $\mathrm{N}$ accumulation and contributed to reducing OSR biomass. The specific composition of the plant mixture did not explain the soil microorganism activity.

Keywords: intercropping; oilseed rape; service plants; companion plant; faba bean; grass pea; niger; soil microorganisms; symbiotic $\mathrm{N}_{2}$ fixation

\section{Introduction}

Oilseed rape (Brassica napus L.) is the second most cultivated oilseed globally and in Europe [1]. Rapeseed is highly sensitive to weeds and insect pests, and receives large amounts of herbicides and insecticides [2]. It also requires substantial amounts of $\mathrm{N}$ and $\mathrm{P}$ fertilisers to sustain high yields [3,4]. The use of these chemical inputs causes environmental and health damage [5-8]. Introducing functional biodiversity in agroecosystems is a means to use biotic interactions to reduce the reliance of agricultural systems on chemicals and enhance ecosystem services [9-11]. Service plants can help achieve such a goal; they are sown to provide ecosystem services to the cash crops and/or to the cropping system, and not to be harvested [12]. Following this aim, intercropping winter oilseed rape (OSR) with frost-sensitive service plants (either legumes or legume-based mixtures) is a practice that has recently shown a fast increase in Switzerland and, to a certain extent, some European countries, such as France.

Intercropping consists of simultaneously growing two crop species or more in the same field during at least a part of their cycles [13]. During the past two decades, a number of studies have highlighted the nature of crop interspecific interactions within intercrops, 
more often a cereal grown with a legume, and relationships with crop performance at harvest and its environmental impact [14-17]. Such practices involve three kinds of interactions between the different species, depending on their traits, growth stages, available resources, and interactions with other organisms, especially microbial communities [14,15,18-20]: (i) competition for resources, (ii) niche complementarity and/or (iii) facilitation. In grainlegume-cereal intercrops, which have been largely investigated, it has been shown that niche complementarity was a key process to explain the benefits of this practice on crop nitrogen status and yields $[14,15]$. In greenhouse experiments, the same trends were observed in OSR-legume mixtures [21-23]. Indeed, in annual crops, during the simultaneous growth of the two companion crops, complementarity for $\mathrm{N}$ use better explains the beneficial results of intercropping than the facilitation process through nitrogen transfer, which has been shown to be effective in forage species pluriannual mixtures [23-26]. Related to niche complementarity for $\mathrm{N}$ sharing and root interactions, an increase in legume $\mathrm{N}_{2}$ fixation, with positive soil fertility consequences, was also evidenced [27-30].

Service plants intercropped with OSR or other Brassicaceae can provide several ecosystem services. For instance, frost sensitive faba bean or lentil could allow a 20 to $40 \mathrm{~kg} \cdot \mathrm{ha}^{-1}$ $\mathrm{N}$ fertilizer reduction without OSR yield loss [12,31]. Service plants can also contribute to weed [12,32], or insect pests control for instance by favouring their natural enemies [33-36]. Studies focusing on OSR-service plant intercropping have mainly focused on simple mixtures including only legumes [12,31,32]. However, farmers may choose to grow more complex mixtures to achieve multiple ecosystem services or to limit the risk of failure [37-39]. Thus, in Switzerland, over $90 \%$ of the service plant mixtures grown with OSR consist of 5 to 11 species, with more than two legumes, such as lentils, vetch, berseem clover, grass pea, fenugreek or faba bean, and at least one non-legume species, such as niger or buckwheat [40].

In such diversified mixtures, the complexity of interactions between plant species and with the soil is high and there is a lack of knowledge on the functional roles of the different plant species. For instance, legumes are often considered as a homogenous functional group based on their ability to fix $\mathrm{N}_{2}$ through symbiosis with rhizobia, and most studies focus on a few model species [30,41]. However, a large diversity within legumes results in large differences among species regarding their ability to fix nitrogen, their sensitivity to environmental conditions, and their effect on the soil $[30,42-48]$. The species traits of legume and non-legume service plants are keys to explaining ecosystem services. Lorin et al. [48] suggested that legume traits favourable to nitrogen provision in frost-sensitive legumes are antagonistic with traits favourable to weed control.

In a large-scale field experiment, Verret et al. [12] highlighted faba bean as one of the most efficient service plants for increasing OSR yield under low fertilization conditions. However, the drivers of the positive effects of faba bean remain unclear, and the potential of this species to enhance ecosystem services within mixtures intercropped with OSR may be underestimated. Presently, in Switzerland, Baux and Schumacher [40] showed that faba bean was only grown in less than $10 \%$ of the mixtures sown with OSR and at a very low density. In addition to complementarity and niche separation processes for $\mathrm{N}$ acquisition, faba bean can benefit the cash crop by improving rhizospheric microbial activity, as shown by Drut et al. [21] in substitutive intercrop designs with OSR or wheat. Rhizosphere microbial communities are shaped by plant cover through rhizodeposition $[49,50]$, which depends on crop species, cultivars, growth stage, and soil properties [51,52], and plays a major role in the interaction network, affecting plant nutrient availability and acquisition [53]. In their review, Richardson et al. [54] underlined that rhizosphere microbial communities might affect plant $\mathrm{N}$ acquisition through the following processes: (i) the increase in the surface or the structure of the root system; (ii) the increase in nutrient availability due to $\mathrm{N}_{2}$ fixation; (iii) the displacement of sorption equilibrium or transformation of nutrients between different pools such as nitrification inhibitors; (iv) the turnover of microorganisms; or (v) the priming effect. In faba bean-wheat intercrops, Wahbi et al. [55] showed better $\mathrm{N}$ and $\mathrm{P}$ accumulation in wheat than in sole crops in relation to soil microorganisms. 
This study aims to improve knowledge about the functional roles of legumes in service plant mixtures sown with OSR. First, from a preliminary greenhouse experiment using species (and the same cultivars) commonly used in Swiss service plant mixtures, we sought to identify those with a potential impact on soil microbial activity. Second, based on the assumption that legumes are key species for enhancing multiple ecosystem services in low-input systems, we selected two of those species with contrasting above ground traits for a second greenhouse experiment. Using mesocosms filled with soil, we compared their effects when they were grown either (i) alone, (ii) together with OSR, or (iii) in the presence of a non-legume service plant. Thus, we investigated the plant-plant and plant-soil interactions, biomass production, and $\mathrm{N}$ and $\mathrm{P}$ status of OSR.

\section{Materials and Methods}

\subsection{Species Choice}

Based on the preliminary greenhouse experiment results in which different species found in the Swiss service plant mixtures were grown in pots (see Supplementary Materials S1, Figure S1), information provided by farmers and literature, two legumes and one Asteraceae were selected for our experiment in mesocosms. The first legume, faba bean (Vicia faba L. cv Fanfare), was chosen for its high capacity to enhance soil microbial activity compared to other crops [21] (Figures S1 and S2) and its high ability to fix $\mathrm{N}_{2}[42,43]$. Faba bean is also known to produce high biomass [43], but its thick and erected above ground parts do not favour quick degradability after freezing, which is essential to make $\mathrm{N}$ available to the OSR before flowering [48]. The second selected legume, grass pea (Lathyrus sativus L. cv Merkur), had among the lowest capacity to enhance soil microbial activity by the MicroResp ${ }^{\mathrm{TM}}$ technique (Figures S1 and S2), a good symbiotic $\mathrm{N}_{2}$ fixing capacity [42], and climbing or prostrate shoots supposed to be more degradable than that of faba bean after freezing. The last service plant selected was niger (Guizotia abyssinica (L.f.) Cass.), a non-N-fixing species with contrasting growing habits, and root and shoot traits, compared to Brassicaceae, and the ability to enhance soil microbial activity [46,47] (Figures S1 and S2). Niger is also found in over $90 \%$ of Swiss service plant mixtures [40]. The OSR (Brassica napus L.) cultivar was the hybrid Avatar, often used in Switzerland.

\subsection{Experimental Design}

The greenhouse experiment was undertaken from 26 March to 6 June 2019 in Angers, France $\left(47^{\circ} 28^{\prime} 0^{\prime \prime} \mathrm{N}, 0^{\circ} 47^{\prime} 31^{\prime \prime} \mathrm{W}\right.$; average temperature $\left.19.2 \pm 2.7^{\circ} \mathrm{C}\right)$. Mesocosms $(12.5 \mathrm{~L}$, $20 \mathrm{~cm}$ diameter, $40 \mathrm{~cm}$ height [56]) were filled with $15.6 \mathrm{~kg}$ of fresh sandy soil (6.8\% clay, $16.4 \%$ silt, $75 \%$ sand, $1.7 \%$ organic matter), sieved at $11 \mathrm{~mm}$, and carefully mixed with $200 \mathrm{~mL}$ of a labelling solution containing $7.7 \mathrm{~g} \cdot \mathrm{L}^{-1} \mathrm{NH}_{4} \mathrm{NO}_{3}$ enriched in ${ }^{15} \mathrm{~N}(0.063$ atom $\%$ $\left.{ }^{15} \mathrm{Nexcess}\right)$. The resulting mineral composition was $22.02 \mathrm{mg} \mathrm{N}-\mathrm{NH}_{4}{ }^{+} \cdot \mathrm{kg}^{-1}$, $2.49 \mathrm{mg} \mathrm{N}-\mathrm{NO}_{3}{ }^{-} \cdot \mathrm{kg}^{-1}, 98 \mathrm{mg} \mathrm{P} \cdot \mathrm{kg}^{-1}$ (Olsen), $381 \mathrm{mg} \mathrm{K} \cdot \mathrm{kg}^{-1}, 205 \mathrm{mg} \mathrm{Mg} \cdot \mathrm{kg}^{-1}$, less than $0.1 \mathrm{mg} \mathrm{CaCO} 3 \cdot \mathrm{kg}^{-1}, \mathrm{pH}_{\mathrm{H} 2 \mathrm{O}}$ 7.2, and 15.1\% humidity. Mesocosm height allowed for root architecture complementarity expression in the early growth, and limitation of competition for soil resource before legume nodulation and nitrogen fixation. A water solution with Rhizobium leguminosarum bv viciae strain P221 [57] was added to each mesocosm $\left(>2.10^{8}\right.$ cells $\cdot$ mesocosm $\left.^{-1}\right)$ to ensure the nodulation of grass pea and faba bean. After inoculation, a $2.5 \mathrm{~cm}$ layer of $\mathrm{N}$-free pure sand was added at the top of each mesocosm to limit evaporation and avoid algae. During the experiment, the soil moisture was maintained between 12 and 17\% humidity to prevent any water deficit and nutrient leaching.

In the mesocosms, plants were grown either in pure species or in mixtures (Figure 1). The seeds were pre-germinated at $20{ }^{\circ} \mathrm{C}$ before sowing. One to five plants were sown per mesocosm to obtain eight modalities $(n=4$; Figure 1$)$ : (i) 1 OSR with 1 grass pea (RG), (ii) 1 OSR with 1 faba bean (RF), (iii) 1 OSR with 1 grass pea and 1 faba bean (RFG), (iv) 2 OSRs with 2 nigers (2R2Ni), (v) 1 OSR with 2 nigers and 1 grass pea (RG2Ni), (vi) 1 OSR with 2 nigers and 1 faba bean (RF2Ni), (vii) 1 OSR with 2 nigers, 1 grass pea and 1 faba bean (RGF2Ni), and (viii) 1 grass pea with one faba bean (GF). Six kinds of control 
treatments were added: (i) 1 OSR (R), (ii) 2 OSRs (2R), (iii) 3 OSRs (3R), (iv) 2 grass peas (2G), (v) 2 faba beans (2F), and (vi) mecososm without plants (0P). The use of two niger plants in $2 \mathrm{R} 2 \mathrm{Ni}, \mathrm{RG} 2 \mathrm{Ni}, \mathrm{RF} 2 \mathrm{Ni}$, and RGF2Ni was based on the proportions of this species in the Swiss mixtures. These 14 treatments were arranged in four complete randomized blocks on culture tables in the same greenhouse.

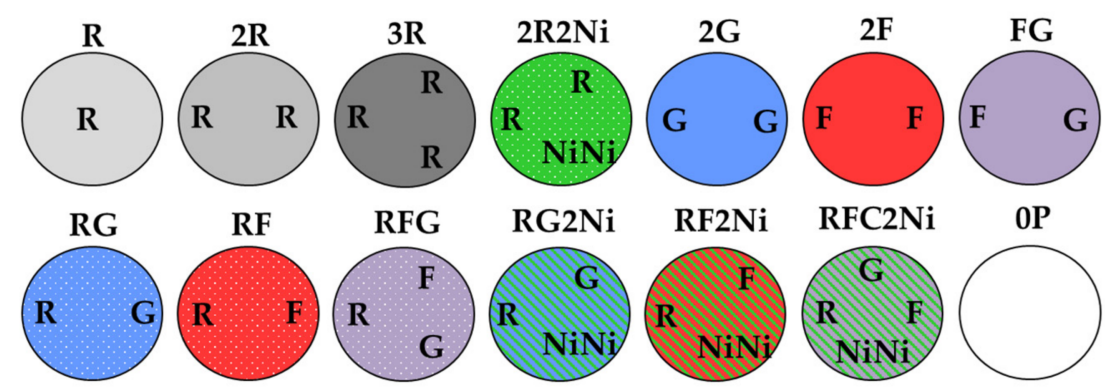

Figure 1. Number of individuals per mesocosm and code of each species in each treatment. R: OSR (Brassica napus L. cv Avatar), F: Faba bean (Vicia faba L. cv Fanfare), G: Grass pea (Lathyrus sativus L. cv Merkur) and Ni: Niger (Guizotia abyssinica (L.f.) Cass.). Each of these abbreviations is an individual plant. OP: No plant.

\subsection{Plant and Soil Sampling and Chemical Analyses}

The plants were harvested once at the end of the experiment, 72 days after sowing. In each mesocosm, the shoot of each plant was harvested separately before pooling per species. As roots were intermingled and difficult to sort by species, they were pooled in a single sample. All plant samples were oven-dried for $72 \mathrm{~h}$ at $60{ }^{\circ} \mathrm{C}$ before weighing. Then, they were ground into a fine powder and prepared for ${ }^{15} \mathrm{~N}:{ }^{14} \mathrm{~N}$ and $\% \mathrm{~N}$ analyses with a mass spectrometer (IsoPrim, Elementar, Hanau, Germany) and elemental analyser (EA3000 EuroVector, Milan, Italy). OSR shoot \%P was measured using a coupled plasma optical emission spectrometer (ICP-OES; Thermo Fisher Scientific iCAP 7400, Waltham, MA, USA).

At harvest, after gentle shaking of the roots, two kinds of soil samples were collected: the soil adherent to the roots (AS) and the non-adherent soil, hereafter called bulk soil (BS). Only for $2 \mathrm{G}$ was the amount of AS too low to collect valuable samples for analyses. The mineral nitrogen concentrations $\left(\mathrm{N}_{-} \mathrm{NO}_{3}{ }^{-}\right.$and $\left.\mathrm{N}-\mathrm{NH}_{4}{ }^{+}\right)$were measured within $\mathrm{BSs}$ using a segmented flow analysis (SKALAR SA3000, Breda, The Netherlands). The $\mathrm{pH}_{\mathrm{H} 2 \mathrm{O}}$ of both ASs and BSs was also measured ( $\mathrm{pH}$ meter Orion 2-star model, Thermo Fisher Scientific, Waltham, MA, USA).

\subsection{Soil Microbial Activity}

The catabolic activity of the soil microbial communities was assessed using the MicroResp ${ }^{\mathrm{TM}}$ method. The ASs and BSs were dried at $30{ }^{\circ} \mathrm{C}$ for $96 \mathrm{~h}$ and stored at $4{ }^{\circ} \mathrm{C}$. Before analysis, the soil was re-humidified and left at $20^{\circ} \mathrm{C}$ without light for 7 days to re-activate the soil microbial communities. Then, the MicroResp ${ }^{\mathrm{TM}}$ method was applied as described by Campbell et al. [58] to assess the quantity of $\mathrm{CO}_{2}$ produced by a given mass of soil reacting for $6 \mathrm{~h}$ at $28{ }^{\circ} \mathrm{C}$ with a fixed quantity of a given substrate, also called substrate-induced respiration (SIR). Substrates used in this study were selected from the literature as parts of the classical crop root exudates [59-62]. They included glucose, arabinose, cellulose, trehalose, aspartate, butyric acid, glutamate, malate, and phytate. Glucose-induced respiration was used as an indicator of active microbial biomass [63-65]. Glucose was also used in association with bronopol and streptomycin as an indicator of active fungal biomass $[21,65]$.

In addition to microbial respiration, the nitrification potential was measured using the method described by Hart et al. [66] on fresh soil stored for 5 days at $4{ }^{\circ} \mathrm{C}$. This method aims to evaluate the potential of a given soil to transform $\mathrm{NH}_{4}{ }^{+}$into $\mathrm{NO}_{3}{ }^{-}$under 
optimal conditions. It consists of mixing $15 \mathrm{~g}$ of fresh soil and $100 \mathrm{~mL}$ of a solution containing $15 \mathrm{mM} \mathrm{NH}_{4}{ }^{+}, 1 \mathrm{mM} \mathrm{PO}_{4}{ }^{3-}$, and a pH of 7.2 in an Erlenmeyer. The solution was homogenised continuously with a magnetic agitator for $24 \mathrm{~h}$ at $20^{\circ} \mathrm{C}$ in the obscurity. After 2, 6, 20, and $24 \mathrm{~h}$ of incubation, $15 \mathrm{~mL}$ of the solution was sampled, centrifuged, and stored at $-18{ }^{\circ} \mathrm{C}$ for subsequent analysis of $\mathrm{N}-\left(\mathrm{NO}_{3}{ }^{-}-\mathrm{NO}_{2}\right)$ contents using a segmented flow analyser (SKALAR SA3000, Breda, The Netherlands). Nitrification potential was obtained by fitting a simple linear model using the least square method between 2 and $24 \mathrm{~h}$ of incubation, resulting in a value expressed in $\mathrm{mg} \mathrm{N}-\left(\mathrm{NO}_{3}{ }^{-}-\mathrm{NO}_{2}\right) \cdot \mathrm{kg}$ dry soil ${ }^{-1} \cdot \mathrm{h}^{-1}$.

\subsection{Calculations}

\subsubsection{Percentage of Nitrogen Derived from Fixation (\%Ndfa)}

In our experiment, we mitigated the spatial ${ }^{15} \mathrm{~N}:{ }^{14} \mathrm{~N}$ ratio homogeneity by using sieved soil carefully mixed with a ${ }^{15} \mathrm{~N}$-enriched labelling solution. Nitrogen derived from biological $\mathrm{N}_{2}$ fixation (\%Ndfa) was thus assessed using the isotopic dilution method [67], using (1):

$$
\% \text { Ndfa }=\left(1-\frac{\text { atom } \%{ }^{15} \mathrm{~N} \text { excess legume }}{\text { atom } \%{ }^{15} \mathrm{~N} \text { excess reference plant }}\right) \times 100
$$

where pure OSRs ( $R, 2 R, 3 R)$ were used as non-fixing reference plants and atom $\%{ }^{15} \mathrm{~N}$ excess of a sample following (2):

$$
\text { atom } \%{ }^{15} \mathrm{~N} \text { excess sample }=\text { atom } \%{ }^{15} \mathrm{~N} \text { sample } \times 100-0.3663
$$

in which 0.3663 is the abundance of ${ }^{15} \mathrm{~N}$ atoms as a percentage of the total $\mathrm{N}$ in the atmosphere, and atom $\%{ }^{15} \mathrm{~N}$ sample is the abundance of ${ }^{15} \mathrm{~N}$ atoms as a percentage of the total nitrogen in the sample.

\subsubsection{Competition Index}

The relative interaction intensity index (RII) [68] was used to compare the effect of intra- vs. interspecific competition within the plurispecific mesocosms for a given species [69]. RII values range from -1 to +1 , with a -1 value corresponding to maximum competition. RII was measured using (3):

$$
\mathrm{RII}=\frac{B_{\text {inter }}-B_{\text {pure }}}{B_{\text {inter }}+B_{\text {pure }}}
$$

where $B_{\text {pure }}$ is the mean dry weight (DW) of individuals measured in monospecific mesocosm and $B_{\text {inter }}$ is the mean DW of individuals measured in intercropping. RII was also calculated for the $\mathrm{N}$ and $\mathrm{P}$ amounts within the shoots.

\subsection{Statistical Analysis}

All statistical analyses and figures were obtained from R software [70]. The results presented in tables and figures are the means \pm standard deviations (SDs) of four replicates. One- or two-way analysis of variance (ANOVA) followed by Tukey's honestly significant difference (HSD) post hoc test was performed. In the case of non-normality of residuals or strong heterogeneity of variance, either outlier was removed, or analysis was undertaken using the Kruskal-Wallis test followed by the Conover post hoc test [71]. Thus, one of the reps of the $\mathrm{R}$ treatment with a leverage $>4$ was removed from the root dry weight ANOVA of Figure 2a. The FG treatment was also removed from the amount of $\mathrm{N}$ in the root ANOVA of Figure $2 b$ due to its much higher SD compared to other treatments. No transformation of data was applied except for the soil mineral $\mathrm{N}$ content, which was log-transformed prior to analysis of variance. One-sample Student's $t$-test was also used to assess whether the RIIs were significantly greater or lower than 0 . 

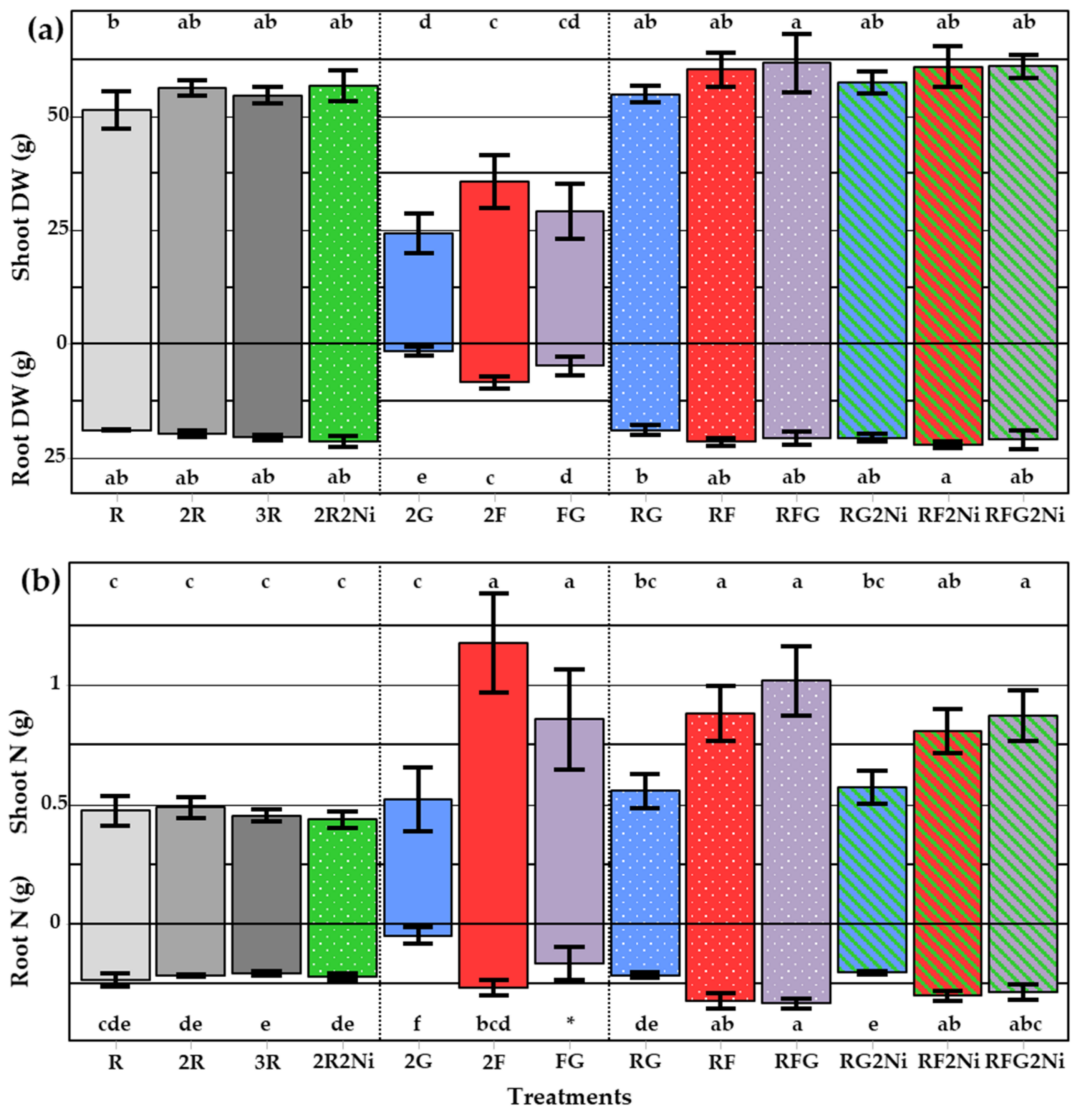

Figure 2. Total shoot and root dry weights (DWs) (a) and total shoot and root $\mathrm{N}$ (b) accumulated per mesocosm. R: OSR (Brassica napus L. cv Avatar), F: Faba bean (Vicia faba L. cv Fanfare), G: Grass pea (Lathyrus sativus L. cv Merkur) and Ni: Niger (Guizotia abyssinica (L.f.) Cass.). Means of four replicates. Error bars are SDs. For all, one-way ANOVA test $p<0.001$. Different letters: a, b, c, d, e indicate significant differences across treatments (Tukey HSD test). *: FG was removed from the root N ANOVA test, see Materials and Methods.

\section{Results}

\subsection{Dry Weight and N Accumulated per Mesocosm}

The plant DWs ranged from 25.9 to $83.1 \mathrm{~g} \cdot$ mesocosm $^{-1}$ in $2 \mathrm{G}$ and RF2Ni, respectively (Figure $2 \mathrm{a}, p<0.001$ ). Total shoot and root DW per mesocosm differed significantly across treatments $(p<0.001$ for shoots and roots). There were no significant differences between either total shoot or root DW per mesocosm between pure OSR $(R, 2 R, 3 R)$ and treatments mixing OSR with other species $(p>0.05)$. Treatments with legumes only $(2 \mathrm{G}, 2 \mathrm{~F}, \mathrm{FG})$ accumulated 30 to $61 \%$ less DW in shoots and 55 to $93 \%$ less DW in roots than those including OSR (Figure 2a, $p<0.001$ for shoots and $p<0.001$ for roots). This was especially clear for pure grass pea $(2 \mathrm{G})$, which had the lowest root biomass.

More variability across treatments was observed for $\mathrm{N}$ accumulated per mesocosm. The presence of faba bean significantly increased the total shoot $\mathrm{N}$ compared with pure OSR (Figure $2 b, p<0.05$ ). The total root $\mathrm{N}$ was less contrasted; however, the RF and RFG treatments accumulated significantly more $\mathrm{N}$ in roots than the pure OSR $(p>0.05)$. Globally, regarding the amount of $\mathrm{N}$ in the plant shoots and roots, the treatments including OSR and faba bean accumulated from 1.11 to $1.35 \mathrm{~g} \mathrm{~N} \cdot$ mesocosm $^{-1}$ in RF2Ni and RFG, respectively. This value was significantly greater than that in treatments with pure OSR or OSR intercropped without faba bean, which reached 0.65 to $0.78 \mathrm{~g} \mathrm{~N} \cdot$ mesocosm $^{-1}$ for 2R2Ni and RG2Ni, respectively (Figure $2 b, p<0.001$ ). Adding nigers to the mixtures RF and RFG tended to decrease the total shoot and root $\mathrm{N}(p=0.0504)$. 


\subsection{Dry Weight, Total $N$ and N Derived from Fixation in Service Plant Species \\ 3.2.1. Shoot Dry Weights and Shoot $\mathrm{N}$ per Species}

The effect of legume species (faba bean or grass pea) and the plant-plant interactions on the legume shoot biomass and $\mathrm{N}$ was assessed through two-way ANOVA. Here, plantplant interactions were defined as a factor with three levels: (i) two legume individuals grown together (2F or $2 \mathrm{G}$ ), (ii) legume OSR intercropping (RF or RG), and (iii) legume grown with OSR and nigers (RF2Ni or RG2Ni). The plant-plant interaction significantly affected legume shoot DWs and $\mathrm{N}$ amounts $(p<0.01$, Table 1$)$. The effect of legume species was also significant $(p<0.001$ for DWs and N amounts, Table 1). Grown in mixtures, the faba bean tended to accumulate approximately 2- to 3-fold more DW (Figure 3a,b) and 3to 5 -fold more $\mathrm{N}$ in the shoots than grass pea (Figure $3 \mathrm{~d}, \mathrm{e}$ ). The interaction between the two factors (legume species and the plant-plant interactions) was not significant $(p>0.05$, Table 1).

Table 1. Effect of legume choice (Leg) and plant-plant interaction (Pl-pl inter)—analysis of variance.

\begin{tabular}{|c|c|c|c|c|c|c|c|c|c|}
\hline \multirow{2}{*}{$\begin{array}{l}\text { Source } \\
\text { of Variance }\end{array}$} & \multicolumn{3}{|c|}{ Legume Biomass } & \multicolumn{3}{|c|}{ Legume N } & \multicolumn{3}{|c|}{$\begin{array}{c}\text { Amount of N Derived from } \\
\text { Biological Fixation }\end{array}$} \\
\hline & Df & F-Value & $p$-Value & Df & F-Value & $p$-Value & Df & F-Value & $p$-Value \\
\hline Leg & 1 & 41.77 & $<0.001^{* * *}$ & 1 & 69.49 & $<0.001^{* * *}$ & 1 & 74.946 & $<0.001^{* * *}$ \\
\hline Pl-pl inter & 2 & 8.088 & $<0.01^{* *}$ & 2 & 7.063 & $<0.01^{* *}$ & 2 & 2.073 & 0.155 \\
\hline $\begin{array}{l}\text { Leg } \times \text { Pl-pl } \\
\text { inter }\end{array}$ & 2 & 1.153 & 0.338 & 2 & 0.372 & 0.694 & 2 & 0.424 & 0.661 \\
\hline Residuals & 18 & & & 18 & & & 18 & & \\
\hline
\end{tabular}

Leg (factor with two levels): Faba bean and Grass pea. Pl-pl inter (factor with three levels): two legume individuals grown together (FF or $\mathrm{GG}$ ), legume-OSR intercropping (RF or RG) and legume grown with OSR and nigers (RF2Ni or RG2Ni). Asterisks indicate the significance of either factor or interaction of effects.

Grass pea above ground DW was markedly reduced in complex mixtures, including more than two species (from $12.1 \mathrm{~g}$ DW.plant ${ }^{-1}$ in $2 \mathrm{G}$ to $3.7 \mathrm{~g}$ DW.plant ${ }^{-1}$ in RFG2Ni, $p<0.05$, Figure 3a). The same trend was observed with $\mathrm{N}$ accumulation $(p<0.05$, Figure $3 \mathrm{~d})$. For faba bean, we did not find any significant differences in above ground DWs or $\mathrm{N}$ amounts across modalities ( $p>0.05$, Figure $3 \mathrm{~b}, \mathrm{e})$.

Niger DW ranged from 4.4 to $7.1 \mathrm{~g} \cdot$ plant $^{-1}$ in $2 \mathrm{R} 2 \mathrm{Ni}$ and RG2Ni, equivalent to 15.8 and $24.7 \%$ of the total mixture DW, respectively. No significant differences were found for niger shoot DW across the mixtures in which it was included (Figure $3 c, p>0.05$ ). Nevertheless, the niger benefited from the presence of the grass pea, but not of that of faba bean, with an amount of $\mathrm{N}$ in shoot 2-fold higher in RG2Ni than in mixtures $2 \mathrm{R} 2 \mathrm{Ni}$ (Figure $3 \mathrm{c}, p<0.01$ ). Regardless of the mixture, the niger had a very low $\mathrm{N}$ concentration and accumulated from 0.03 to $0.05 \mathrm{~g} \mathrm{~N} \cdot$ plant $^{-1}$ (Figure $3 \mathrm{c}, \mathrm{f}$ ). As mixtures with niger always comprised two individuals, they represented 0.06 to $0.1 \mathrm{~g} \mathrm{~N} \cdot$ mesocosm $^{-1}$ and 13.6 to $17.8 \%$ of the accumulated $\mathrm{N}$ of the total mesocosm shoots in treatments without faba bean. This proportion was smaller than that of the treatments including faba bean: $9.2 \%$ for both RF2Ni and RFG2Ni.

\subsubsection{Nitrogen Derived from Biological Fixation in the Legumes}

In faba bean, the amount of nitrogen derived from biological fixation was significantly higher than that of grass pea $(p<0.001$, Table 1$)$. We did not find a significant effect of the plant-plant interactions on the amount of nitrogen fixed by legumes $(p=0.155$, Table 1$)$.

When grass pea or faba bean was intercropped with OSR, the \%Ndfa tended to increase for both legume species compared to the pure legume treatment $(2 \mathrm{G}$ and $2 \mathrm{~F})$. Pure grass pea \%Ndfa was $14 \%$ compared to $51-65 \%$ in treatments with OSR (RG, RFG, RG2Ni and RFG2Ni). However, these differences were significant only between $2 \mathrm{G}$ and the most complex mixture, including grass pea: RFG2Ni $(p<0.05$, Table 2$)$. For faba bean, the \%Ndfa was clearly higher in intercrops than in $2 \mathrm{~F}$ but was similar across the mixtures, 
including OSR ( $p<0.01$, Table 2 ), from 54\% (in 2F) to 88-90\% (in RF, RFG, RF2Ni, and RFG2Ni, $p<0.05)$. The variance in $\%$ Ndfa was much higher for grass pea than for faba bean when the legume was intercropped $(12.5 \leq$ SDs $\leq 35.3 \%$ for grass pea and $0.9 \leq$ SDs $\leq 2.2 \%$ for faba bean, Table 2 ).
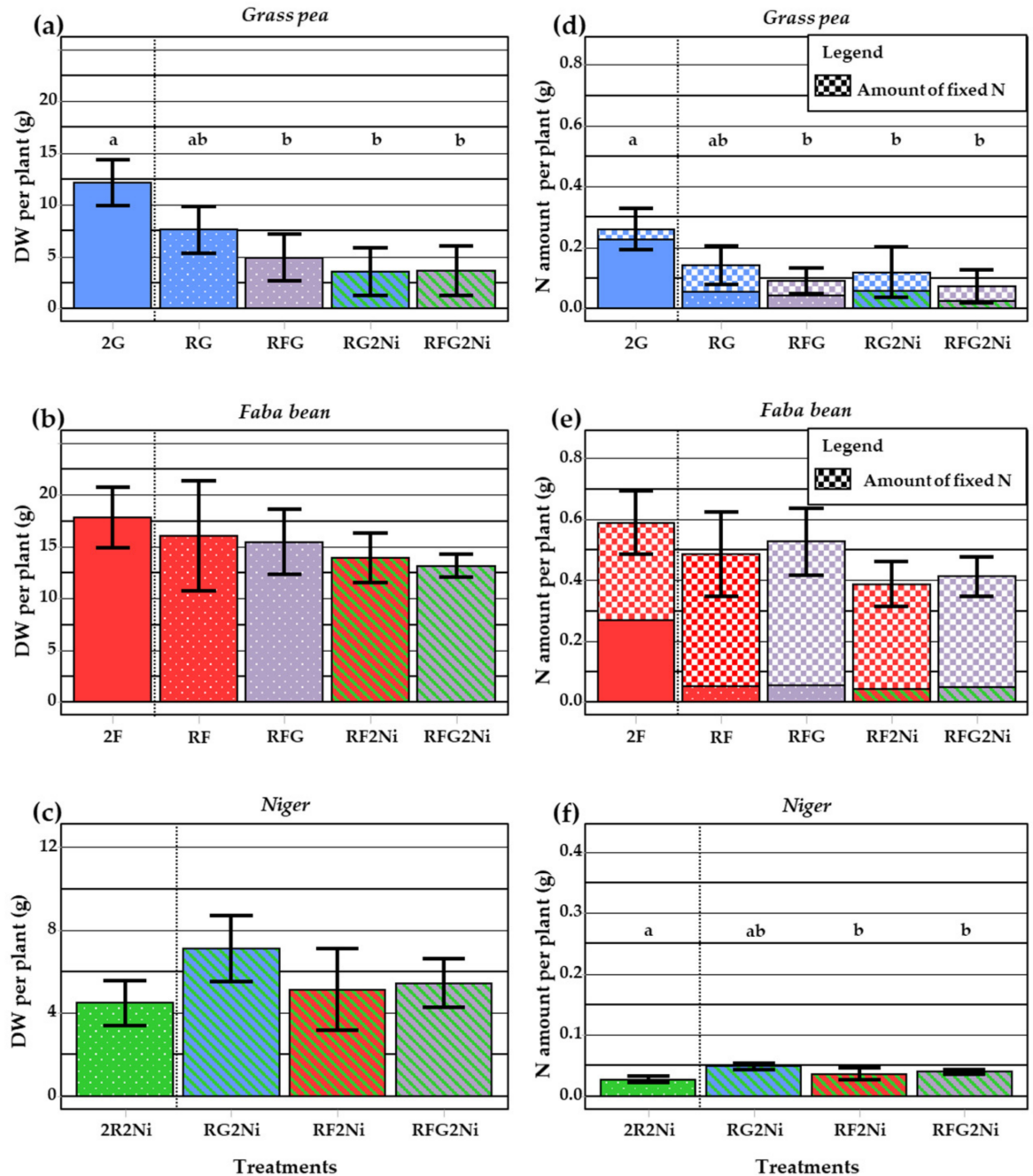

Figure 3. Above ground dry weight $(\mathbf{a}-\mathbf{c})$, and $\mathrm{N}(\mathbf{d}-\mathbf{f})$ in service plants $\left(g \cdot\right.$ plant $\left.^{-1}\right)$. R: OSR (Brassica napus L. cv Avatar), F: Faba bean (Vicia faba L. cv Fanfare), G: Grass pea (Lathyrus sativus L. cv Merkur) and Ni: Niger (Guizotia abyssinica (L.f.) Cass.). Means of four replicates. Error bars are SDs. When one-way ANOVA had $p<0.05$, the different letters a and $\mathrm{b}$ indicate significant differences across treatments (Tukey HSD).

Table 2. Percentage of nitrogen derived from biological fixation (\%Ndfa) in legumes service plants.

\begin{tabular}{cccccccc}
\hline & 2F/2G & FG & RF/RG & RFG & RF2Ni/RG2Ni & RFG2Ni & $p$-Value \\
\hline Grass pea & $14 \pm 13.9 \mathrm{~b}$ & $16 \pm 5.9 \mathrm{ab}$ & $63 \pm 20.8 \mathrm{ab}$ & $52 \pm 31.9 \mathrm{ab}$ & $51 \pm 35.3 \mathrm{ab}$ & $65 \pm 12.5 \mathrm{a}$ & $<0.05^{*}$ \\
Faba bean & $54 \pm 8.7 \mathrm{c}$ & $71 \pm 8.3 \mathrm{bc}$ & $90 \pm 0.9 \mathrm{a}$ & $90 \pm 2.2 \mathrm{a}$ & $89 \pm 1.6 \mathrm{ab}$ & $88 \pm 0.9 \mathrm{ab}$ & $<0.001 * *$ \\
\hline
\end{tabular}

R: OSR (Brassica napus L. cv Avatar), F: Faba bean (Vicia faba L. cv Fanfare), G: Grass pea (Lathyrus sativus L. cv Merkur) and Ni: Niger (Guizotia abyssinica (L.f.) Cass.). Figures are means of four replicates \pm SD. The $p$-value results from one-way ANOVA and Kruskal-Wallis tests for grass pea and faba bean, respectively. Asterisks indicate the significance of either factor or interaction of effects. Different letters: a, $\mathrm{b}$, and $\mathrm{c}$ indicate significant differences across treatments according to Tukey HSD test for grass pea and Conover post hoc test for faba bean. 


\subsubsection{Oilseed Rape Dry Weight and N, P Status}

The greater the number of OSR plants $(R, 2 R, 3 R)$, the lower the shoot DW, N, and $\mathrm{P}$ accumulation per plant $(p<0.05$, Figure 4$)$. In our experiment, the addition of a single legume to OSR had a non-significant impact on OSR shoot DW and P $(p>0.05)$. Conversely to more complex mixtures, OSR shoot DW and P accumulation decreased first with the addition of the two legume species, second with the addition of the niger plants, and third, with the addition of the grass pea and the two niger plants $(p<0.05)$. Regarding the shoot $\mathrm{N}$, grass pea had no impact on OSR, but faba bean alone reduced the amount of $\mathrm{N}$ accumulated by OSR $(p<0.05)$. RFG2Ni was the only mixture in which OSR shoots did not significantly accumulate more DW, N, and P than $2 \mathrm{R}(p>0.05$, Figure 4$)$.

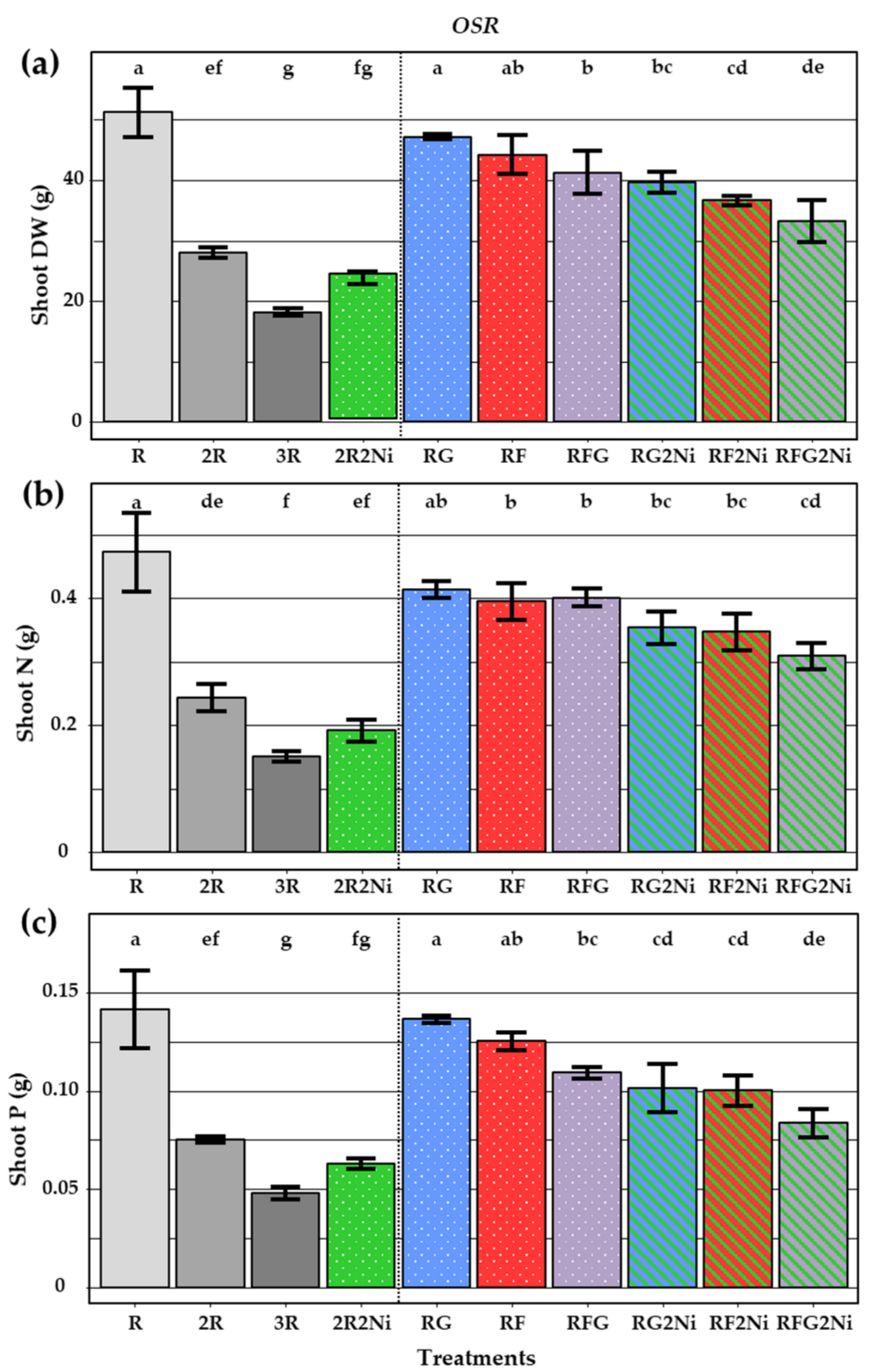

Figure 4. Dry weight (DW) (a), N (b) and P (c) in OSR shoots. R: OSR (Brassica napus L. cv Avatar), F: Faba bean (Vicia faba L. cv Fanfare), G: Grass pea (Lathyrus sativus L. cv Merkur) and Ni: Niger (Guizotia abyssinica (L.f.) Cass.). Means of four replicates. Error bars are SDs. For all the KruskalWallis $(\mathbf{a}, \mathbf{c})$ and one-way ANOVA $(\mathbf{b})$ tests $p<0.001$, the letters $\mathrm{a}, \mathrm{b}, \mathrm{c}, \mathrm{d}$, e, and $\mathrm{f}$ represent the groups of significantly different modalities according to the Conover post hoc test $(\mathbf{a}, \mathbf{c})$ or the Tukey HSD test (b). 
When treatments with a similar number of components were compared, the substitution of a non-legume species (one OSR or two nigers) by a legume led to a significant increase in DW, N, and P per OSR plant. The addition of two nigers to a mixture led to a significant decrease in DW and P accumulation $(p<0.05$, Figure $4 \mathrm{a}, \mathrm{c})$. Regarding N, the difference was only significant for RFG, where the addition of nigers (RFG2Ni) led to a drop of $23 \%$ of the $\mathrm{N}$ accumulation per OSR plant $(p<0.05$, Figure $4 \mathrm{a})$.

\subsubsection{Interactions between Plants}

The relative interaction indexes (RIIs) assess the strength of interspecific competition compared to intraspecific competition. The OSR RII was significantly higher than 0 for the DW, N, and P when a legume plant was substituted for an OSR plant $(p<0.001)$. The strength of interspecific competition did not significantly differ when the OSR was intercropped with either faba bean or grass pea, except for $\mathrm{P}$, where grass pea had a significantly higher RII than faba bean $(0.25$ and 0.29 , respectively; $p<0.01)$.

The RII standard deviation values of OSR were much less variable $(0.01<$ SDs < 0.06) than those of legumes, for which competition strength was much more variable; for faba bean and grass pea, SDs ranged from 0.16 to 0.27 and 0.16 to 0.31 , respectively. For grass pea, the strength of intraspecific competition was significantly lower than that of interspecific competition with OSR ( $\mathrm{RII}<0, p<0.05$ for DW and N). The competition strength of faba bean intercropped with OSR did not significantly differ from that of pure stands, as the RII was not significantly smaller than 0 ( $p>0.05$ for DW and N).

\subsection{Soil Properties}

\subsubsection{Chemical Analyses}

At harvest, the remnant mineral $\mathrm{N}$ in the BSs ranged from 1 to $1.3 \mathrm{mg}$ $\mathrm{N}-\left(\mathrm{NH}_{4}{ }^{+}, \mathrm{NO}_{3}{ }^{-}\right) \cdot \mathrm{kg}^{-1}$ dry soil and did not differ among the treatments with OSR $(p>0.05)$. The soil mineral $\mathrm{N}$ was greater in $2 \mathrm{G}, 2 \mathrm{~F}$ and $\mathrm{FG}$ than in mesocosms with OSR, with values between 10.8 and $4.7 \mathrm{mg} \mathrm{N}-\left(\mathrm{NH}_{4}{ }^{+}, \mathrm{NO}_{3}{ }^{-}\right) \cdot \mathrm{kg}^{-1}$ of dry soil for $2 \mathrm{G}$ and $2 \mathrm{~F}$, respectively $(p<0.05$, Table S2). The $\mathrm{pH}$ of ASs and BSs did not vary across treatments $(p>0.05)$, except the $\mathrm{pH}$ of control bare soil (0P), which was lower than any other BS treatment $\mathrm{pH}(p<0.001$, Table S2).

\subsubsection{Soil Microbial Activity}

PCAs summarizing the substrate-induced respiration (SIR) values of ASs and BSs (Figure 5) showed that in both cases, the control soil (OP) tended to have a lower SIR than the other treatments. In the control bare soil (OP), the glucose-induced respiration differed significantly from the bulk soil samples of the mesocosms with OSR and faba bean (RF, RFG, RF2Ni, and RFG2Ni), in addition to those including grass pea, niger, and OSR (RG2Ni, $p<0.01$ ). No significant differences were found for any other substrate (Table S1). The tests of the linear correlation between plant DW and glucose-induced respiration were positive and significant for both AS and BS, with $\mathrm{r}^{2}$ values of 0.26 and 0.23 , respectively ( $p<0.001$, Figure S3). The same was true for glucose-induced respiration with the addition of antibiotics, with $\mathrm{r}^{2}$ values of 0.32 and 0.19 for AS and BS, respectively $(p<0.001$, Figure S3).

The nitrification potential did not follow a clear pattern. We observed that the higher density of OSR with two or three plants tended to have a higher potential for nitrification than one plant. These results also suggest that the FG and RG treatments had a lower nitrification potential, but these differences were non-significant (Table S2). 


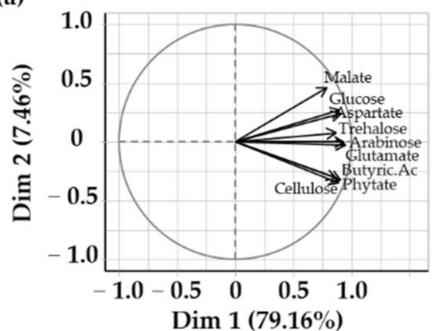

(c)

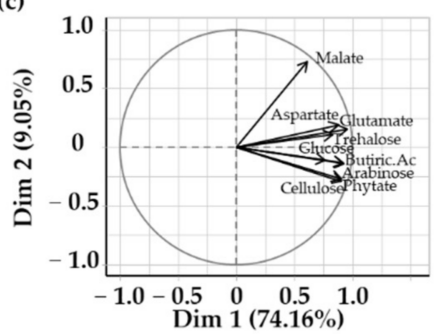

(b)

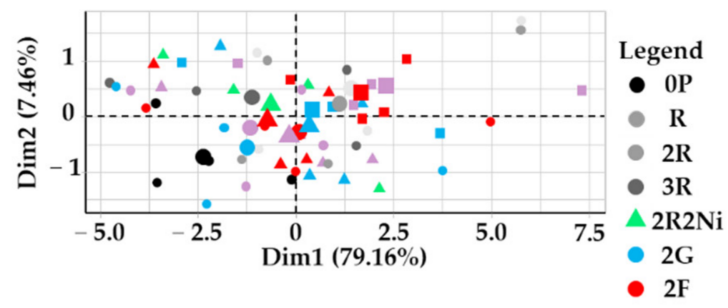

(d)

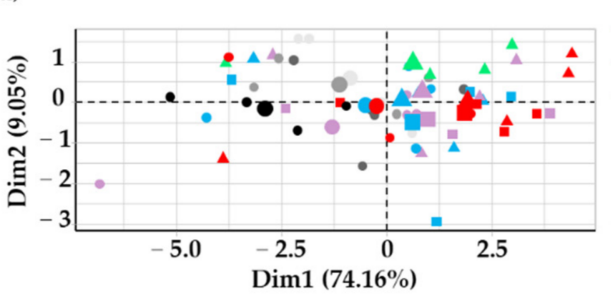

FG

A RG

$\Delta \mathrm{RF}$

$\triangle$ RFG

RG2Ni

- RF2Ni

- RFG2Ni

Figure 5. PCA based on SIR measurement of 12 substrates of the different treatments on the adherent soil $(\mathbf{a}, \mathbf{b})$ and bulk soil $(\mathbf{c}, \mathbf{d})$. The small points/triangle/scars represent the repetitions, and the large points represent the average of the four replicates of a treatment. R: OSR (Brassica napus L. cV Avatar), F: Faba bean (Vicia faba L. cv Fanfare), G: Grass pea (Lathyrus sativus L. cv Merkur) and Ni: Niger (Guizotia abyssinica (L.f.) Cass.). 0P: No plant. The detailed data are presented in Table S1 (Supplementary Materials). There was no significant difference between treatments.

\section{Discussion}

\subsection{Drivers of DW and N Accumulation in the Service Plant Mixtures}

In our study, the highest total plant biomass was achieved in treatments with OSR. The addition of multiple species to OSR led to only marginal and non-significant increases in biomass. Regarding the total $\mathrm{N}$ accumulated in the shoots, the treatments with faba bean reached the highest values. This result is consistent with the greenhouse experiment presented in Freund et al. [72], who compared two component mixtures made of pea, mustard, and oat in a substitutive design and observed that the mixtures' total DW and $\mathrm{N}$ were mostly driven by a single species: pea. The field study of Schappert et al. [73], who compared three-component cover crop mixtures with pure stands in a substitutive design, observed that none of the mixtures reached a higher DW than pure stands. In our experiment, the total DW and $\mathrm{N}$ accumulation were both driven mainly by a single species: either OSR or faba bean. This result emphasizes the fact that two different species can contribute to shaping plant community traits and functioning, here through DW and accumulation of $\mathrm{N}$ by plants.

Consequently, different species can contribute to achieving different ecosystem services, which is one of the goals of mixing multiple species in agro-ecosystems to increase primary production and community stability $[74,75]$. We neither observed relationships between species diversity and total DW or N, nor transgressive overyielding in the current experiment, even though the species had contrasting traits. This was observed when the treatments were compared from either a substitutive or an additive standpoint. However, additive or substitutive legume-Brassicaceae intercropping has often been reported to increase the total plant biomass in field experiments [74,75]. These differences can probably be explained by the growing conditions of the experiment that are addressed later in this discussion.

\subsection{Grass Pea and Faba Bean: Two Contrasting Legumes}

Grass pea and faba bean are two contrasting legumes grown either in pure stands or intercropped. Grown alone, grass pea produced lower biomass than faba bean; this was especially true for root biomass. In our experiment, both legume species tended to have a higher \%Ndfa when intercropped with OSR compared to pure stands. The increase in 
legume $\mathrm{N}_{2}$ fixation under low mineral nitrogen conditions or in intercropping has been widely documented [29,30,76-78]. Conversely to our original hypothesis, the addition of niger to the OSR-legume mixture did not lead to a further increase in legume \%Ndfa.

Faba bean \%Ndfa in pure stands was $54 \%$, compared to $14 \%$ for grass pea. The high ability of faba bean to fix nitrogen under non-limiting mineral nitrogen conditions is consistent with the observations of Guinet et al. [44], Turpin et al. [79], and Dayoub et al. [43]. The trends for grass pea suggest that the $\% \mathrm{Ndfa}$ of this species is more sensitive to mineral nitrogen than faba bean. Moreover, the \%Ndfa of grass pea was much more variable than that of faba bean. Many factors could explain this variability, including less adapted rhizobium strength or microbial consortia, even if the inoculation came in addition to the naturally occurring microbial community of a freshly gathered agricultural soil. Several authors demonstrated the impact of this factor and the mineral composition of the soil on the legume \% Ndfa $[79,80]$. It is interesting to acknowledge that the biomass and $\mathrm{N}$ accumulated by grass pea also followed the same pattern as \%Ndfa within a modality, which was not the case for faba bean. This species had a higher and less variable \%Ndfa.

The relationships between the legume \%Ndfa and legume DW make clear that niche complementarity for $\mathrm{N}$ nutrition is a key interaction to explain the ability of a legume to produce biomass in intercropping with OSR, which is a plant with a high ability to absorb soil mineral nitrogen. If we compare the intensity of competition (RII) across studies, it is interesting to see that the RII of faba bean intercropped with OSR ranged from -0.11 to 0.06 in Jamont et al. [23], Drut et al. [21], and our experiment, when Génard et al. [22] obtained values ranging from -0.28 to -0.49 for other legumes, and we obtained -0.23 for grass pea.

\subsection{Consequences of Service Plants on Winter Oilseed Rape Growth}

In our experiment, the addition of either both faba bean and grass pea or niger decreased the OSR biomass. This result is consistent with the study of Verret et al. [12] on winter OSR-service plant intercropping that showed an OSR biomass reduction of $18 \%$ when intercropped with legume service plants and $56 \%$ with non-legume in early winter. However, the intraspecific competition was stronger than that of service plants. One legume and two niger plants had a significantly lower impact than another OSR on OSR DW. Treatment with OSR, faba bean, grass pea, and nigers also tended to show higher biomass than the modality with two OSR plants.

In faba bean-OSR intercropping, Jamont et al. [23] noted that before faba been nodules start to fix $\mathrm{N}_{2}$, and thus, feed on another $\mathrm{N}$ pool than that of the soil, the two species harbour complementary root architecture limiting competition for the soil resource. Our experiment was thus undertaken in $40 \mathrm{~cm}$-tall mesocosms to allow better expression of root architectures in early growth before nodulation, to enhance niche separation and limit competition between plant species. However, in these conditions, the rooting depth is limited to $40 \mathrm{~cm}$ for the later stages, and niche separation such as that observed in peabarley intercropping grown in the field $[81,82]$ cannot occur in such a mesocosm system. Nevertheless, in field conditions OSR could also be grown in soil as shallow as $30 \mathrm{~cm}$, where the rooting depth is also limited. At harvest, in the mesocosms, as root systems were intermingled, it was not possible to sort them for $\mathrm{N}$ and ${ }^{15} \mathrm{~N}:{ }^{14} \mathrm{~N}$ ratio measurements. As a consequence, plant $\mathrm{N}$ status and $\mathrm{N}$ derived from biological fixation were assessed based on values measured from the shoots, which is consistent with methods usually used in the field.

Plant-plant and plant-microorganism interactions are both highly dependent on growing conditions and especially on resource availability e.g., [83-86]. At the end of our experiment, the soil mineral nitrogen concentration was very low in the treatments with OSR (less than $1.5 \mathrm{mg} \cdot \mathrm{kg}^{-1}$ dry soil), and the total amount of $\mathrm{N}$ of pure OSR at different densities remained stable, meaning that $\mathrm{N}$ was a strong limiting factor. The OSR biomass per plant was higher than that in other similar studies, even if the thermal time of the current experiment was lower [21-23]. This emphasizes the fact that even 
if soil mineral $\mathrm{N}$ availability limited the growing conditions, our experiment was more favourable to OSR growth. This is also the case for faba bean growth, to a lesser extent. As a result, OSR intraspecific competition was much higher in our experiment than in the other experiments, explaining the difference in RII between our experiment $(0.22$ and 0.25 for OSR intercropped with faba bean and grass pea, respectively) compared to values that ranged from 0.05 to 0.13 in other studies [21-23].

\subsection{Microbial Activity}

We did not observe any significant change in the soil microbial activity between the different treatments, which is not consistent with Drut et al. [21], who found a significant positive effect of faba bean on soil SIR in pure stands, in addition to intercropping with either OSR or wheat. The difference could be linked to the cultivars we used, as root exudates and their impact on soil microorganisms depend on the genotype $[87,88]$. The soil characteristics could also explain this different result, as competition for $\mathrm{N}$ between plant and soil microorganisms is a key process that contributes to shaping microbial communities $[89,90]$. Even if differences between sole crops and intercropping have often been reported $[19,54,91]$, it is important to see that these differences are context dependent. Regardless of the species mixture composition, we did observe a correlation between plant biomass and glucose SIR, which is an indicator of soil microbial active biomass (Figure S3).

\subsection{Which Species to Mix for Which Services?}

Farmers who mix several species could target different goals, such as maximizing the level of one ecosystem service, optimizing trade-offs between services/dis-services in order to achieve more than one ecosystem service or reduce the risk of service plant growth failure $[23,37-39]$.

Under our growing conditions, grass pea did not increase the total biomass or $\mathrm{N}$ accumulation and only fixed a small amount of nitrogen. This species is likely to provide little if any $\mathrm{N}$ supply service when the competition with the cash crop is high. Finding that accessions or breeding cultivars with a higher ability to fix $\mathrm{N}_{2}$ and a higher capacity to sustain high biomass under low $\mathrm{N}$ conditions could contribute to making this species a more efficient service plant for both weed control and $\mathrm{N}$ provision to OSR in spring. It would also allow us to take advantage of the growing habit complementarity between faba bean and grass pea. In addition, it is interesting to underline that faba bean did not accumulate more soil $\mathrm{N}$ than grass pea but fixed much more nitrogen. The low sensitivity to competition of faba bean and its limited impact on OSR could explain why this species was reported as particularly interesting in field experiments [12]. Faba bean also provides extra-floral nectar, which can be an important food source for female parasitoids, thus enhancing those natural enemies' fitness [36]. As a result, it seems appropriate to introduce faba bean more frequently in mixtures of service species associated with OSR.

As non-legume, niger relies on the soil mineral $\mathrm{N}$. This trait enhances competition with OSR, as observed in our experiment. However, competition for soil mineral $\mathrm{N}$ could also be a key factor for weed control, and non-legumes are often more efficient than legumes to achieve this goal $[12,92,93]$. Non-legume service plants such as camelina or buckwheat can drastically reduce OSR biomass and grain yield [12]. In our experiment, niger impacted OSR biomass but not strongly, probably due to its low $\% \mathrm{~N}$ and late development in the very early stage.

The three service plants studied here have different effects on $\mathrm{N}$ fluxes and resource sharing, and could also potentially combine one or several other ecosystem services, such as weed control, pollinator feeding, or contribution to insect pest regulation, due to a more favourable environment for their natural enemies or a confusion effect, which we did not assess in this study. 


\section{Conclusions}

OSR intercropped with single or multiple service plant species in limiting $\mathrm{N}$ conditions showed that the mixture growth was mostly driven by a single species, either OSR for DW or faba bean for $\mathrm{N}$ accumulation. This result highlights the fact that a species that does not dominate the biomass can shape the plant cover traits. Our results emphasize that legume service species should not be considered to be a homogenous functional group and can potentially combine several ecosystem services. Grass pea was significantly more impacted by competition with non-legume species. It produced a small amount of biomass and fixed a low quantity of $\mathrm{N}_{2}$. The \%Ndfa of legumes was increased when intercropped with OSR compared to pure stands. However, another non-legume addition did not lead to a further increase in \% Ndfa and tended to decrease the total $\mathrm{N}$ accumulation of service plants. The results from this experiment can thus contribute to better understand plant-plant interaction mechanisms at the early stage of such intercropping, which are key to selecting the relevant species to compose a mixture according to targeted ecosystem services and local conditions. The results also provide references for improving the genetics of service plants with the aim of increasing the efficiency of mixtures intercropped with OSR or other cash crops in a context of chemical input limitation and climate change.

Supplementary Materials: The following are available online at https:/ / www.mdpi.com/article/ 10.3390 /agronomy11081493/s1, S1. Methods and materials screening of service plants according to soil induced respiration, Figure S1. Substrate induced respiration by glucose of the adherent soil of 16 species, Figure S2. Substrate induced respiration profile of 10 plant species, Table S1. $p$-values of ANOVA of different substrates effect on substrate-induced respiration across mixtures in soil adherent to roots and bulk soil, Figure S3. Linear relation between total plant biomass and substrate-induced respiration of glucose with or without antibiotic in soil adherent to roots or bulk soil, Table S2. pH mineral N contents and potential nitrification of the soil.

Author Contributions: Conceptualization, X.B., N.C. and J.F.; methodology, X.B., N.C. and J.F.; formal analysis, X.B., N.C., J.M.H. and J.F.; investigation, X.B., N.C., M.H. and J.F.; data curation, X.B. and J.F.; writing-original draft preparation, X.B., N.C. and J.F.; writing-review and editing, X.B., N.C., A.B., M.V.-M., J.M.H., M.L., M.H. and J.F.; funding acquisition, A.B., M.V.-M. and J.F. All authors have read and agreed to the published version of the manuscript.

Funding: This research was funded by Agroscope (Swiss confederation), UFA Samen, Florin and Nurtriswiss as part of the ICARO project.

Institutional Review Board Statement: Not applicable.

Informed Consent Statement: Not available.

Data Availability Statement: The data presented in this study are available on request from the corresponding author.

Acknowledgments: We thank Sylvie Vincent, Julien Poret and Vincent Oury, in addition to the other members of the technical team of the LEVA, for their valuable technical assistance. We are most grateful to the PLATIN' (Plateau d'Isotopie de Normandie) core facility for $\mathrm{N}$ element and isotope analyses. We thank SADEF for the analysis of $\mathrm{P}$ contents in plants.

Conflicts of Interest: The authors declare no conflict of interest. The funders had no role in the design of the study; in the collection, analyses, or interpretation of data; in the writing of the manuscript; or in the decision to publish the results.

\section{References}

1. FAO. FAOSTAT. Available online: http:/ /www.fao.org/faostat/en/\#home (accessed on 2 May 2020).

2. Valantin-Morison, M.; Meynard, J. Diagnosis of limiting factors of organic oilseed rape yield. A survey of farmers' fields. Agron. Sustain. Dev. 2008, 28, 527-539. [CrossRef]

3. Rathke, G.-W.; Behrens, T.; Diepenbrock, W. Integrated nitrogen management strategies to improve seed yield, oil content and nitrogen efficiency of winter oilseed rape (Brassica napus L.): A review. Agric. Ecosyst. Environ. 2006, 117, 80-108. [CrossRef]

4. Bélanger, G.; Ziadi, N.; Pageau, D.; Grant, C.; Lafond, J.; Nyiraneza, J. Shoot growth, phosphorus-nitrogen relationships, and yield of canola in response to mineral phosphorus fertilization. Agron. J. 2015, 107, 1458-1464. [CrossRef] 
5. Tilman, D.; Fargione, J.; Wolff, B.; D’antonio, C.; Dobson, A.; Howarth, R.; Schindler, D.; Schlesinger, W.H.; Simberloff, D.; Swackhamer, D. Forecasting agriculturally driven global environmental change. Science 2001, 292, 281-284. [CrossRef]

6. Crews, T.; Peoples, M. Legume versus fertilizer sources of nitrogen: Ecological tradeoffs and human needs. Agric. Ecosyst. Environ. 2004, 102, 279-297. [CrossRef]

7. IPCC. Climate Change 2014: Mitigation of Climate Change; Contribution of Working Group III to the Fifth Assessment Report of the Intergovernmental Panel on Climate Change; Cambridge University Press: Cambridge, UK, 2014; p. 1435.

8. Kim, K.-H.; Kabir, E.; Jahan, S.A. Exposure to pesticides and the associated human health effects. Sci. Total Environ. 2017, 575, 525-535. [CrossRef] [PubMed]

9. Altieri, M.A. The ecological role of biodiversity in agroecosystems. Agric. Ecosyst. Environ. 1999, 74, 19-31. [CrossRef]

10. Duru, M.; Therond, O.; Martin, G.; Martin-Clouaire, R.; Magne, M.-A.; Justes, E.; Journet, E.-P.; Aubertot, J.-N.; Savary, S.; Bergez, J.-E. How to implement biodiversity-based agriculture to enhance ecosystem services: A review. Agron. Sustain. Dev. 2015, 35, 1259-1281. [CrossRef]

11. Gaba, S.; Lescourret, F.; Boudsocq, S.; Enjalbert, J.; Hinsinger, P.; Journet, E.-P.; Navas, M.-L.; Wery, J.; Louarn, G.; Malézieux, E. Multiple cropping systems as drivers for providing multiple ecosystem services: From concepts to design. Agron. Sustain. Dev. 2015, 35, 607-623. [CrossRef]

12. Verret, V.; Gardarin, A.; Makowski, D.; Lorin, M.; Cadoux, S.; Butier, A.; Valantin-Morison, M. Assessment of the benefits of frost-sensitive companion plants in winter rapeseed. Eur. J. Agron. 2017, 91, 93-103. [CrossRef]

13. Willey, R. Intercropping: Its importance and research needs. Part 1 Competition and crop yield advantages. Field Crop Abstr. 1979, $32,1-10$.

14. Bedoussac, L.; Journet, E.-P.; Hauggaard-Nielsen, H.; Naudin, C.; Corre-Hellou, G.; Jensen, E.S.; Prieur, L.; Justes, E. Ecological principles underlying the increase of productivity achieved by cereal-grain legume intercrops in organic farming: A review. Agron. Sustain. Dev. 2015, 35, 911-935. [CrossRef]

15. Brooker, R.W.; Bennett, A.E.; Cong, W.F.; Daniell, T.J.; George, T.S.; Hallett, P.D.; Hawes, C.; Iannetta, P.P.; Jones, H.G.; Karley, A.J. Improving intercropping: A synthesis of research in agronomy, plant physiology and ecology. New Phytol. 2015, 206, 107-117. [CrossRef]

16. Malézieux, E.; Crozat, Y.; Dupraz, C.; Laurans, M.; Makowski, D.; Ozier-Lafontaine, H.; Rapidel, B.; De Tourdonnet, S.; ValantinMorison, M. Mixing plant species in cropping systems: Concepts, tools and models: A review. Agron. Sustain. Dev. 2009, 29, 43-62. [CrossRef]

17. Pelzer, E.; Bazot, M.; Makowski, D.; Corre-Hellou, G.; Naudin, C.; Al Rifaï, M.; Baranger, E.; Bedoussac, L.; Biarnès, V.; Boucheny, P. Pea-wheat intercrops in low-input conditions combine high economic performances and low environmental impacts. Eur. J. Agron. 2012, 40, 39-53. [CrossRef]

18. Dowling, A.; Sadras, V.O.; Roberts, P.; Doolette, A.; Zhou, Y.; Denton, M.D. Legume-oilseed intercropping in mechanised broadacre agriculture-A review. Field Crops Res. 2021, 260, 107980. [CrossRef]

19. Duchene, O.; Vian, J.-F.; Celette, F. Intercropping with legume for agroecological cropping systems: Complementarity and facilitation processes and the importance of soil microorganisms: A review. Agric. Ecosyst. Environ. 2017, 240, 148-161. [CrossRef]

20. Hinsinger, P.; Betencourt, E.; Bernard, L.; Brauman, A.; Plassard, C.; Shen, J.; Tang, X.; Zhang, F. P for two, sharing a scarce resource: Soil phosphorus acquisition in the rhizosphere of intercropped species. Plant Physiol. 2011, 156, 1078-1086. [CrossRef]

21. Drut, B.; Cassagne, N.; Cannavacciuolo, M.; Le Floch, G.; Cobo, J.; Fustec, J. Mobilization of interactions between functional diversity of plant and soil organisms on nitrogen availability and use. Asp. Appl. Biol. 2018, 138, 31-42.

22. Génard, T.; Etienne, P.; Diquélou, S.; Yvin, J.-C.; Revellin, C.; Laîné, P. Rapeseed-legume intercrops: Plant growth and nitrogen balance in early stages of growth and development. Heliyon 2017, 3, e00261. [CrossRef] [PubMed]

23. Jamont, M.; Piva, G.; Fustec, J. Sharing N resources in the early growth of rapeseed intercropped with faba bean: Does $\mathrm{N}$ transfer matter? Plant Soil 2013, 371, 641-653. [CrossRef]

24. Carlsson, G.; Huss-Danell, K. Nitrogen fixation in perennial forage legumes in the field. Plant Soil 2003, 253, 353-372. [CrossRef]

25. Thilakarathna, M.S.; McElroy, M.S.; Chapagain, T.; Papadopoulos, Y.A.; Raizada, M.N. Belowground nitrogen transfer from legumes to non-legumes under managed herbaceous cropping systems. A review. Agron. Sustain. Dev. 2016, 36, 58. [CrossRef]

26. Louarn, G.; Pereira-Lopès, E.; Fustec, J.; Mary, B.; Voisin, A.-S.; de Faccio Carvalho, P.C.; Gastal, F. The amounts and dynamics of nitrogen transfer to grasses differ in alfalfa and white clover-based grass-legume mixtures as a result of rooting strategies and rhizodeposit quality. Plant Soil 2015, 389, 289-305. [CrossRef]

27. Andersen, M.K.; Hauggaard-Nielsen, H.; Ambus, P.; Jensen, E.S. Biomass production, symbiotic nitrogen fixation and inorganic $\mathrm{N}$ use in dual and tri-component annual intercrops. Plant Soil 2005, 266, 273-287. [CrossRef]

28. Corre-Hellou, G.; Fustec, J.; Crozat, Y. Interspecific competition for soil $\mathrm{N}$ and its interaction with $\mathrm{N}_{2}$ fixation, leaf expansion and crop growth in pea-barley intercrops. Plant Soil 2006, 282, 195-208. [CrossRef]

29. Jensen, E.S. Grain yield, symbiotic $\mathrm{N}_{2}$ fixation and interspecific competition for inorganic $\mathrm{N}$ in pea-barley intercrops. Plant Soil 1996, 182, 25-38. [CrossRef]

30. Rodriguez, C.; Carlsson, G.; Englund, J.-E.; Flöhr, A.; Pelzer, E.; Jeuffroy, M.-H.; Makowski, D.; Jensen, E.S. Grain legume-cereal intercropping enhances the use of soil-derived and biologically fixed nitrogen in temperate agroecosystems: A meta-analysis. Eur. J. Agron. 2020, 118, 126077. [CrossRef] 
31. Lorin, M.; Jeuffroy, M.-H.; Butier, A.; Valantin-Morison, M. Undersowing winter oilseed rape with frost-sensitive legume living mulch: Consequences for cash crop nitrogen nutrition. Field Crops Res. 2016, 193, 24-33. [CrossRef]

32. Lorin, M.; Jeuffroy, M.-H.; Butier, A.; Valantin-Morison, M. Undersowing winter oilseed rape with frost-sensitive legume living mulches to improve weed control. Eur. J. Agron. 2015, 71, 96-105. [CrossRef]

33. Cadoux, S.; Sauzet, G.; Valantin-Morison, M.; Pontet, C.; Champolivier, L.; Robert, C.; Lieven, J.; Flénet, F.; Mangenot, O.; Fauvin, P. Intercropping frost-sensitive legume crops with winter oilseed rape reduces weed competition, insect damage, and improves nitrogen use efficiency. OCL 2015, 22, D302. [CrossRef]

34. Altieri, M.A.; Gliessman, S.R. Effects of plant diversity on the density and herbivory of the flea beetle, Phyllotreta cruciferae Goeze, in California collard (Brassica oleracea) cropping systems. Crop Prot. 1983, 2, 497-501. [CrossRef]

35. Altieri, M.A.; Wilson, R.C.; Schmidt, L.L. The effects of living mulches and weed cover on the dynamics of foliage-and soilarthropod communities in three crop systems. Crop Prot. 1985, 4, 201-213. [CrossRef]

36. Jamont, M.; Crépellière, S.; Jaloux, B. Effect of extrafloral nectar provisioning on the performance of the adult parasitoid Diaeretiella rapae. Biol. Control 2013, 65, 271-277. [CrossRef]

37. Wendling, M.; Charles, R.; Herrera, J.; Amossé, C.; Jeangros, B.; Walter, A.; Büchi, L. Effect of species identity and diversity on biomass production and its stability in cover crop mixtures. Agric. Ecosyst. Environ. 2019, 281, 81-91. [CrossRef]

38. Finney, D.M.; Murrell, E.G.; White, C.M.; Baraibar, B.; Barbercheck, M.E.; Bradley, B.A.; Cornelisse, S.; Hunter, M.C.; Kaye, J.P.; Mortensen, D.A.; et al. Ecosystem services and disservices are bundled in simple and diverse cover cropping systems. Agric. Environ. Lett. 2017, 2, 170033. [CrossRef]

39. Finney, D.M.; White, C.M.; Kaye, J.P. Biomass production and carbon/nitrogen ratio influence ecosystem services from cover crop mixtures. Agron. J. 2016, 108, 39-52. [CrossRef]

40. Baux, A.; Schumacher, P. Dévelopement du colza associé: Avis des producteurs suisses. Rech. Agron. Suisse 2019, 10, 128-133.

41. Magrini, M.-B.; Cabanac, G.; Lascialfari, M.; Plumecocq, G.; Amiot, M.-J.; Anton, M.; Arvisenet, G.; Baranger, A.; Bedoussac, L.; Chardigny, J.-M. Peer-reviewed literature on grain legume species in the WoS (1980-2018): A comparative analysis of soybean and pulses. Sustainability 2019, 11, 6833. [CrossRef]

42. Büchi, L.; Gebhard, C.-A.; Liebisch, F.; Sinaj, S.; Ramseier, H.; Charles, R. Accumulation of biologically fixed nitrogen by legumes cultivated as cover crops in Switzerland. Plant Soil 2015, 393, 163-175. [CrossRef]

43. Dayoub, E.; Naudin, C.; Piva, G.; Shirtliffe, S.J.; Fustec, J.; Corre-Hellou, G. Traits affecting early season nitrogen uptake in nine legume species. Heliyon 2017, 3, e00244. [CrossRef]

44. Guinet, M.; Nicolardot, B.; Revellin, C.; Durey, V.; Carlsson, G.; Voisin, A.-S. Comparative effect of inorganic N on plant growth and $\mathrm{N}_{2}$ fixation of ten legume crops: Towards a better understanding of the differential response among species. Plant Soil 2018, 432, 207-227. [CrossRef]

45. Taylor, B.N.; Simms, E.L.; Komatsu, K.J. More than a functional group: Diversity within the legume-rhizobia mutualism and Its relationship with ecosystem function. Diversity 2020, 12, 50. [CrossRef]

46. Wendling, M.; Büchi, L.; Amossé, C.; Sinaj, S.; Walter, A.; Charles, R. Influence of root and leaf traits on the uptake of nutrients in cover crops. Plant Soil 2016, 409, 419-434. [CrossRef]

47. Tribouillois, H.; Fort, F.; Cruz, P.; Charles, R.; Flores, O.; Garnier, E.; Justes, E. A functional characterisation of a wide range of cover crop species: Growth and nitrogen acquisition rates, leaf traits and ecological strategies. PLoS ONE 2015, 10, e0122156. [CrossRef]

48. Lorin, M.; Butier, A.; Jeuffroy, M.; Valantin-Morison, M. Choisir et gérer des légumineuses gélives associées au colza d’hiver pour le contrôle des adventices et la fourniture d'azote. Innov. Agron. 2017, 60, 77-89.

49. Paterson, E.; Gebbing, T.; Abel, C.; Sim, A.; Telfer, G. Rhizodeposition shapes rhizosphere microbial community structure in organic soil. New Phytol. 2007, 173, 600-610. [CrossRef]

50. Taschen, E.; Amenc, L.; Tournier, E.; Deleporte, P.; Malagoli, P.; Fustec, J.; Bru, D.; Philippot, L.; Bernard, L. Cereal-legume intercropping modifies the dynamics of the active rhizospheric bacterial community. Rhizosphere 2017, 3, 191-195. [CrossRef]

51. Bobille, H.; Limami, A.M.; Robins, R.J.; Cukier, C.; Le Floch, G.; Fustec, J. Evolution of the amino acid fingerprint in the unsterilized rhizosphere of a legume in relation to plant maturity. Soil. Biol. Biochem. 2016, 101, 226-236. [CrossRef]

52. Fustec, J.; Lesuffleur, F.; Mahieu, S.; Cliquet, J.-B. Nitrogen rhizodeposition of legumes. A review. Agron. Sustain. Dev. 2010, 30, 57-66. [CrossRef]

53. Dennis, P.G.; Miller, A.J.; Hirsch, P.R. Are root exudates more important than other sources of rhizodeposits in structuring rhizosphere bacterial communities? FEMS Microbiol. Ecol. 2010, 72, 313-327. [CrossRef] [PubMed]

54. Richardson, A.E.; Barea, J.-M.; McNeill, A.M.; Prigent-Combaret, C. Acquisition of phosphorus and nitrogen in the rhizosphere and plant growth promotion by microorganisms. Plant Soil 2009, 321, 305-339. [CrossRef]

55. Wahbi, S.; Prin, Y.; Thioulouse, J.; Sanguin, H.; Baudoin, E.; Maghraoui, T.; Oufdou, K.; Le Roux, C.; Galiana, A.; Hafidi, M. Impact of wheat/faba bean mixed cropping or rotation systems on soil microbial functionalities. Front. Plant Sci. 2016, 7, 1364. [CrossRef]

56. Drut, B.; Cassagne, N.; Mario, C.; Le Floch, G.; Cobo-Díaz, J.F.; Fustec, J. Improving complementarity effect of legume intercrop by earthworm facilitation for wheat performance. J. Agric. Sci. 2018, 10, 1-14. [CrossRef]

57. Laguerre, G.; Mazurier, S.I.; Amarger, N. Plasmid profiles and restriction fragment length polymorphism of Rhizobium leguminosarum bv. viciae in field populations. FEMS Microbiol. Lett. 1992, 101, 17-26. [CrossRef] 
58. Campbell, C.D.; Chapman, S.J.; Cameron, C.M.; Davidson, M.S.; Potts, J.M. A rapid microtiter plate method to measure carbon dioxide evolved from carbon substrate amendments so as to determine the physiological profiles of soil microbial communities by using whole soil. Appl. Environ. Microbiol. 2003, 69, 3593-3599. [CrossRef] [PubMed]

59. Brechenmacher, L.; Lei, Z.; Libault, M.; Findley, S.; Sugawara, M.; Sadowsky, M.J.; Sumner, L.W.; Stacey, G. Soybean metabolites regulated in root hairs in response to the symbiotic bacterium Bradyrhizobium japonicum. Plant Physiol. 2010, 153, 1808-1822. [CrossRef] [PubMed]

60. Vančura, V. Root exudates of plants. Plant Soil 1964, 21, 231-248. [CrossRef]

61. Turner, B.L.; Papházy, M.J.; Haygarth, P.M.; McKelvie, I.D. Inositol phosphates in the environment. Philos. Trans. R. Soc. Lond. B Ser. B Biol. Sci. 2002, 357, 449-469. [CrossRef]

62. Dakora, F.D.; Phillips, D.A. Root exudates as mediators of mineral acquisition in low-nutrient environments. Plant Soil 2002, 245, 35-47. [CrossRef]

63. Anderson, J.P.; Domsch, K.H. A physiological method for the quantitative measurement of microbial biomass in soils. Soil Biol. Biochem. 1978, 10, 215-221. [CrossRef]

64. Anderson, T.H.; Domsch, K.H. Determination of ecophysiological maintenance carbon requirements of soil microorganisms in a dormant state. Biol. Fertil. Soils 1985, 1, 81-89. [CrossRef]

65. Sassi, M.B.; Dollinger, J.; Renault, P.; Tlili, A.; Bérard, A. The FungiResp method: An application of the MicroResp ${ }^{\mathrm{TM}}$ method to assess fungi in microbial communities as soil biological indicators. Ecol. Indic. 2012, 23, 482-490. [CrossRef]

66. Hart, S.C.; Stark, J.M.; Davidson, E.A.; Firestone, M.K. Nitrogen mineralization, immobilization, and nitrification. In Methods of Soil Analysis: Part 2 Microbiological and Biochemical Properties; Weaver, R.W., Angle, S., Bottomley, P., Bezdicek, D., Smith, S., Tabatabai, A., Wollum, A., Eds.; Soil Science Society of America, Inc.: Madison, WI, USA, 1994; Volume 5, pp. $985-1018$.

67. McAuliffe, C.; Chamblee, D.S.; Uribe-Arango, H.; Woodhouse, W.W., Jr. Influence of inorganic nitrogen on nitrogen fixation by legumes as revealed by N15 1. Agron. J. 1958, 50, 334-337. [CrossRef]

68. Armas, C.; Ordiales, R.; Pugnaire, F.I. Measuring plant interactions: A new comparative index. Ecology 2004, 85, 2682-2686. [CrossRef]

69. Coulis, M.; Bernard, L.; Gerard, F.; Hinsinger, P.; Plassard, C.; Villeneuve, M.; Blanchart, E. Endogeic earthworms modify soil phosphorus, plant growth and interactions in a legume-cereal intercrop. Plant Soil 2014, 379, 149-160. [CrossRef]

70. R Core Team. R: A Language and Environment for Statistical Computing; R Foundation for Statistical Computing: Vienna, Austria, 2020; Available online: https: / /www.R-project.org/ (accessed on 1 December 2020).

71. Pohlert, T. The Pairwise Multiple Comparison of Mean Ranks Package (PMCMR). Available online: https://CRAN.R-project. org / package=PMCMR (accessed on 1 December 2020).

72. Freund, L.; Mariotte, P.; Santonja, M.; Buttler, A.; Jeangros, B. Species identity, rather than species mixtures, drives cover crop effects on nutrient partitioning in unfertilized agricultural soil. Plant Soil 2020, 460, 149-162. [CrossRef]

73. Schappert, A.; Schumacher, M.; Gerhards, R. Weed control ability of single sown cover crops compared to species mixtures Agronomy 2019, 9, 294. [CrossRef]

74. Tilman, D.; Knops, J.; Wedin, D.; Reich, P.; Ritchie, M.; Siemann, E. The influence of functional diversity and composition on ecosystem processes. Science 1997, 277, 1300-1302. [CrossRef]

75. Wendling, M.; Büchi, L.; Amossé, C.; Jeangros, B.; Walter, A.; Charles, R. Specific interactions leading to transgressive overyielding in cover crop mixtures. Agric. Ecosyst. Environ. 2017, 241, 88-99. [CrossRef]

76. Fan, F.; Zhang, F.; Song, Y.; Sun, J.; Bao, X.; Guo, T.; Li, L. Nitrogen fixation of faba bean (Vicia faba L.) interacting with a non-legume in two contrasting intercropping systems. Plant Soil 2006, 283, 275-286. [CrossRef]

77. Naudin, C.; Corre-Hellou, G.; Pineau, S.; Crozat, Y.; Jeuffroy, M.-H. The effect of various dynamics of N availability on winter pea-wheat intercrops: Crop growth, $\mathrm{N}$ partitioning and symbiotic $\mathrm{N}_{2}$ fixation. Field Crops Res. 2010, 119, 2-11. [CrossRef]

78. Streeter, J.; Wong, P.P. Inhibition of legume nodule formation and $\mathrm{N}_{2}$ fixation by nitrate. Crit. Rev. Plant Sci. 1988, 7, 1-23. [CrossRef]

79. Turpin, J.; Herridge, D.; Robertson, M. Nitrogen fixation and soil nitrate interactions in field-grown chickpea (Cicer arietinum) and fababean (Vicia faba). Aust. J. Agric. Res. 2002, 53, 599-608. [CrossRef]

80. Martínez-Hidalgo, P.; Hirsch, A.M. The nodule microbiome: $\mathrm{N}_{2}$-fixing rhizobia do not live alone. Phytobiomes 2017, 1, 70-82. [CrossRef]

81. Corre-Hellou, G.; Crozat, Y. Assessment of Root System Dynamics of Species Grown in Mixtures under Field Conditions using Herbicide Injection and ${ }^{15} \mathrm{~N}$ Natural Abundance Methods: A Case Study with Pea, Barley and Mustard. Plant Soil 2005, 276, 177-192. [CrossRef]

82. Hauggaard-Nielsen, H.; Ambus, P.; Jensen, E.S. Temporal and spatial distribution of roots and competition for nitrogen in pea-barley intercrops-A field study employing ${ }^{32} \mathrm{P}$ technique. Plant Soil 2001, 236, 63-74. [CrossRef]

83. Amossé, C.; Jeuffroy, M.-H.; Celette, F.; David, C. Relay-intercropped forage legumes help to control weeds in organic grain production. Eur. J. Agron. 2013, 49, 158-167. [CrossRef]

84. Bowsher, A.W.; Evans, S.; Tiemann, L.K.; Friesen, M.L. Effects of soil nitrogen availability on rhizodeposition in plants: A review. Plant Soil 2018, 423, 59-85. [CrossRef]

85. Hauggaard-Nielsen, H.; Ambus, P.; Jensen, E.S. Interspecific competition, $\mathrm{N}$ use and interference with weeds in pea-barley intercropping. Field Crops Res. 2001, 70, 101-109. [CrossRef] 
86. Xu, Q.; Wang, X.; Tang, C. The effects of elevated $\mathrm{CO}_{2}$ and nitrogen availability on rhizosphere priming of soil organic matter under wheat and white lupin. Plant Soil 2018, 425, 375-387. [CrossRef]

87. Brolsma, K.M.; Vonk, J.A.; Mommer, L.; Van Ruijven, J.; Hoffland, E.; De Goede, R.G. Microbial catabolic diversity in and beyond the rhizosphere of plant species and plant genotypes. Pedobiologia 2017, 61, 43-49. [CrossRef]

88. Mwafulirwa, L.; Baggs, E.M.; Russell, J.; George, T.; Morley, N.; Sim, A.; de la Fuente Cantó, C.; Paterson, E. Barley genotype influences stabilization of rhizodeposition-derived C and soil organic matter mineralization. Soil Biol. Biochem. 2016, 95, 60-69. [CrossRef]

89. Kaye, J.P.; Hart, S.C. Competition for nitrogen between plants and soil microorganisms. Trends Ecol. Evol. 1997, 12, 139-143. [CrossRef]

90. Moreau, D.; Pivato, B.; Bru, D.; Busset, H.; Deau, F.; Faivre, C.; Matejicek, A.; Strbik, F.; Philippot, L.; Mougel, C. Plant traits related to nitrogen uptake influence plant-microbe competition. Ecology 2015, 96, 2300-2310. [CrossRef]

91. Song, Y.N.; Marschner, P.; Li, L.; Bao, X.G.; Sun, J.H.; Zhang, F.S. Community composition of ammonia-oxidizing bacteria in the rhizosphere of intercropped wheat (Triticum aestivum L.), maize (Zea mays L.), and faba bean (Vicia faba L.). Biol. Fertil. Soils 2007, 44, 307-314. [CrossRef]

92. Corre-Hellou, G.; Dibet, A.; Hauggaard-Nielsen, H.; Crozat, Y.; Gooding, M.; Ambus, P.; Dahlmann, C.; von Fragstein, P.; Pristeri, A.; Monti, M. The competitive ability of pea-barley intercrops against weeds and the interactions with crop productivity and soil $\mathrm{N}$ availability. Field Crops Res. 2011, 122, 264-272. [CrossRef]

93. Cheriere, T.; Lorin, M.; Corre-Hellou, G. Species choice and spatial arrangement in soybean-based intercropping: Levers that drive yield and weed control. Field Crops Res. 2020, 256, 107923. [CrossRef] 